\title{
Substituted Tetrahydroisoquinolines as Microtubule-destabilizing Agents in Triple Negative Human Breast Cancer Cells
}

\author{
MADHAVI GANGAPURAM, RICCARDO JEAN, ELIZABETH MAZZIO, RAMESH BADISA, \\ SURESH EYUNNI, CARL B. GOODMAN, KINFE K. REDDA and KARAM F. SOLIMAN
}

College of Pharmacy and Pharmaceutical Sciences, Florida A\&M University, Tallahassee, FL, U.S.A.

\begin{abstract}
Triple-negative breast cancer (TNBC) occurs at greater frequency amongst African-Americans, being characterized by the absence of estrogen receptor (ER), progesterone receptor $(P R)$ and human epidermal receptor 2 (HER2). TNBC is often invasive and typically treated with cytostatic agents such as taxanes in combination with anthracyclines or platinum-based drugs. In this study, we synthesized a number of tetrahydroisoquinoline moieties by $\mathrm{N}$ amination of substituted isoquinolines by O-mesytelene sulfonylhydroxylamine followed by ylide formation and reduction, which yielded the desired, substituted tetrahydroisoquinolines (THIQs) in moderate to good yield. Using a differential scatter plot to identify potential selective ERmodulating drugs in ER-positive control cells (MCF-7) driven by estradiol vs. TNBC (MDA-MB-231) cells, the in vitro data showed an absence of effects on the ER (compared to 4-hydroxytamoxifen and raloxifene). In contrast, two lead compounds halted proliferation (cytostatic) in MDA-MB-231 TNBC cells at a potency level below $2.5 \mu M$ concomitant with mitotic arrest, attenuated replicative DNA synthesis, halted microtubule nucleation/stunted tubulin polymerization, abnormal expansive cytoskeletal tubulin and actin morphologies with multinucleation of cells. The most effective cytostatic compounds GM-4-53 and GM-3-121 blocked replicative processes at the $G_{2}$ growth phase. These findings suggest that specific THIQs work independently of the ER, by holding static the microtubule network thereby preventing mitosis. Future work is required to establish the safety
\end{abstract}

This article is freely accessible online.

Correspondence to: Karam F.A. Soliman, Ph.D., Distinguished Professor, College of Pharmacy \& Pharmaceutical Sciences, Florida A\&M University, Room 104 Dyson Pharmacy Building, 1520 ML King Blvd, Tallahassee, FL 32307, U.S.A. Tel: +1 8505993306, Fax: +1 8505993667, e-mail: karam.soliman@famu.edu

Key Words: Triple-negative breast cancer, taxanes, tetrahydroisoquinolines. and efficacy of these drugs and their potential adjunct therapeutic gain in the presence of taxanes in TNBC.

Triple-negative breast cancer (TNBC) is highly invasive and associated with greater rates of mortality in AfricanAmericans (1). TNBC is typically associated with the breast cancer type 1 susceptibility protein (BRCA1), p53 mutation, characterized by the lack of estrogen receptor (ER), progesterone (PR) receptor and human epidermal growth factor receptor 2 (HER2) (2-4). Treating this type of malignancy excludes application of hormone-based drugs, rendering heavy reliance on taxane-based drugs, such as paclitaxel with combined treatment of anthracyclines (5) or subsequent platinum-based therapies (6). Paclitaxel mediates its effects through acting as a cytostatic agent, which impairs cell division through paralyzing microtubule dynamics and suppressing detachment from centrosomes. However, its use can bring on multidrug resistance, rendering few available options for terminally ill patients facing aggressive TNBC (7).

Recently, reports have suggested that natural or synthesized tetrahydroisoquinoline derivatives (THIQs) could serve as a potential class of drugs for breast cancer some of which target the overexpression of P-glycoproteins $(8,9)$, overcome multidrug resistance (10), impair migration and invasion (11), and exert antiproliferative effects (12-14) by inducing cell cycle arrest at $G_{2} / M$ phase (15). In our recent studies, we reported the synthesis of THIQs by $N$-amination of isoquinoline using hydroxylamine-O-sulfonic acid followed by ylide formation and reduction, which yielded the desired, $N$-substituted THIQs (16-18). In this study, we evaluated the effects of these THIQs on growth parameters in TNBC cells.

\section{Materials and Methods}

Hanks balanced salt solution (HBSS), [4-(2-hydroxyethyl)-1piperazine-ethanesulfonic acid] (HEPES), ethanol, 24-well plates, 96-well plates, general reagents and supplies were all purchased from Sigma-Aldrich Co. (St. Louis, MO, USA) and VWR 
International (Radnor, PA, USA). Imaging probes were supplied by Life Technologies (Grand Island, NY, USA).

Synthesis. Synthesis of THIQs has been previously described (1618) for GM-3-121. The synthesis of GM-4-53 was accomplished following the same General procedure as described in our earlier work. O-mesitylene sulfonyl hydroxylamine (MSH) (3) was used to prepare the $N$-amino salt as an aminating agent as described (19). An ice cooled solution of 7-hydroxyisoquinoline (2.0 g, 13.78 $\mathrm{mmol}$ ) in $30 \mathrm{ml}$ of dry methylene chloride, and $15 \mathrm{ml}$ of dry methanol was added drop wise to $O$-mesitylenesulfonylhydroxylamine $(2.97 \mathrm{~g}, 13.78 \mathrm{mmol})$ in $10 \mathrm{ml}$ of dry methylene chloride over $5 \mathrm{~min}$ with stirring. The reaction stirred at $0^{\circ} \mathrm{C}$. for $6 \mathrm{~h} .70 \mathrm{ml}$ of ether was added and the suspension filtered. The precipitate was recrystallized from ethyl acetate to give 2-amino-7-hydroxyisoquinolinium 2,4,6-trimethylbenzenesulfonate in $60.5 \%$ yield. Isolated products were used as such in further reactions.

General procedure for acylation. An ice-cold solution of 2-amino-7hydroxyisoquinolinium 2,4,6-trimethylbenzenesulfonate $(8 \mathrm{mmol})$ in $25 \mathrm{ml}$ of anhydrous tetrahydrofuran (THF) containing triethylamine, was added to a 4-ethylbenzoyl chloride $(12 \mathrm{mmol})$ with stirring. The reaction was allowed to proceed for $12 \mathrm{~h}$ at $70^{\circ} \mathrm{C}$. After cooling to room temperature, the reaction was quenched by adding $25 \mathrm{ml}$ of saturated aqueous sodium bicarbonate solution. The mixture was repeatedly shaken in a separation funnel and allowed to stand for few minutes. Extraction with dichloromethane $(2 \times 100 \mathrm{ml})$, and drying over anhydrous sodium sulfate, and removal of the solvent in vacuo gave the crude product that was purified by combiflash chromatography using ethyl acetate:dichloromethane $(3: 2 \mathrm{v} / \mathrm{v})$ as an eluent. The ylide was obtained as light yellow solid in 50\% yield. ${ }^{\mathbf{1}} \mathbf{H N M R}\left(\mathbf{C D C l}_{\mathbf{3}}\right) \delta$ (ppm): 1.26 (t, 3H, J=7.5 Hz, $-\mathrm{CH}_{2}-\mathrm{CH}_{3}$ ), 2.66-2.75 (q, 2H, J=8.1, $\left.7.8 \mathrm{~Hz},-\mathrm{CH}_{2}-\mathrm{CH}_{3}\right), 7.28\left(\mathrm{~d}, 2 \mathrm{H}, \mathrm{J}=8.7 \mathrm{~Hz}, \mathrm{C}_{3}, \mathrm{C}_{5}-\mathrm{H}\right), 7.39(\mathrm{~d}, 1 \mathrm{H}$, $\left.\mathrm{J}=2.1 \mathrm{~Hz}, \mathrm{C}_{8}-\mathrm{H}\right), 7.84\left(\mathrm{~d}, 1 \mathrm{H}, \mathrm{J}=5.7 \mathrm{~Hz}, \mathrm{C}_{6}-\mathrm{H}\right), 7.99(\mathrm{~d}, 1 \mathrm{H}, \mathrm{J}=2.1 \mathrm{~Hz}$, $\left.\mathrm{C}_{5}-\mathrm{H}\right), 8.05\left(\mathrm{~d}, 2 \mathrm{H}, \mathrm{J}=8.1 \mathrm{~Hz}, \mathrm{C}_{4}-\mathrm{H}\right), 8.17\left(\mathrm{~d}, 2 \mathrm{H}, \mathrm{J}=8.4 \mathrm{~Hz}, \mathrm{C}_{2}, \mathrm{C}_{6},-\right.$ $\mathrm{H}), 8.51\left(\mathrm{~d}, 1 \mathrm{H}, \mathrm{J}=6.0 \mathrm{~Hz}, \mathrm{C}_{3}-\mathrm{H}\right), 9.9\left(\mathrm{~s}, 1 \mathrm{H}, \mathrm{C}_{1}-\mathrm{H}\right)$.

General procedure for reduction. A solution of ylide $(5 \mathrm{mmol})$ in 20 $\mathrm{ml}$ of absolute ethanol was added drop-wise to a solution of sodium borohydride $(50 \mathrm{mmol})$ in $25 \mathrm{ml}$ of absolute ethanol pre-cooled to $0^{\circ} \mathrm{C}$. The reaction was allowed to proceed for $5-7 \mathrm{~h}$ at $0^{\circ} \mathrm{C}$ with stirring. Water $(35 \mathrm{ml})$ was added, and allowed to warm up to room temperature. Extraction with dichloromethane $(3 \times 50 \mathrm{ml})$, drying over anhydrous sodium sulfate, and removal of the solvent in vacuo gave the crude product, which was purified by combiflash chromatography using ethyl acetate:hexane $(2: 3 \mathrm{v} / \mathrm{v})$ as an eluent to afford pure 4-ethyl- $N$-(7-hydroxy-3,4-dihydroisoquinolin-2-(1H)-yl)benzamide (GM-4-53) as a white solid in 65.0\% yield. ${ }^{\mathbf{1}} \mathbf{H N M R}\left(\mathbf{C D C l}_{\mathbf{3}}\right) \delta$ (ppm): 1.18 (t, 3H, J=7.5 Hz, $\left.-\mathrm{CH}_{2}-\mathrm{CH}_{3}\right), 2.64-2.72$ (q, 2H, J=7.5 $\left.\mathrm{Hz},-\mathrm{CH}_{2}-\mathrm{CH}_{3}\right), 2.86\left(\mathrm{t}, 2 \mathrm{H}, \mathrm{J}=6.0 \mathrm{~Hz}, \mathrm{C}_{4}-\mathrm{H}\right), 3.18(\mathrm{t}, 2 \mathrm{H}, \mathrm{J}=5.7 \mathrm{~Hz}$, $\left.\mathrm{C}_{3}-\mathrm{H}\right), 3.94(\mathrm{~s}, 2 \mathrm{H}, \mathrm{C} 1-\mathrm{H}), 6.35\left(\mathrm{~d}, 1 \mathrm{H}, \mathrm{J}=2.1,1.8 \mathrm{~Hz}, \mathrm{C}_{8}-\mathrm{H}\right), 6.58$ (dd, 1H, J=2.7, 5.4 Hz, C $6-\mathrm{H}), 6.79$ (d, 1H, J=8.4 Hz, C $5-\mathrm{H}), 7.09$ (s, $1 \mathrm{H},-\mathrm{NH}, \mathrm{D}_{2} \mathrm{O}$ exchange), $7.17\left(\mathrm{~d}, 2 \mathrm{H}, \mathrm{J}=8.1 \mathrm{~Hz}, \mathrm{C}_{3}, \mathrm{C}_{5},-\mathrm{H}\right)$, $7.65\left(\mathrm{~d}, 2 \mathrm{H}, \mathrm{J}=8.1 \mathrm{~Hz}, \mathrm{C}_{2}, \mathrm{C}_{6},-\mathrm{H}\right)$.

Cell culture. MDA-MB-231 (ATCC ${ }^{\circledR}$ HTB-26 ${ }^{\mathrm{TM}}$ ) human breast cancer cells were obtained from the American Type Culture Collection (ATCC) (Manassas, VA, USA). MDA-MB-231 cells were

\section{GM-4-53}

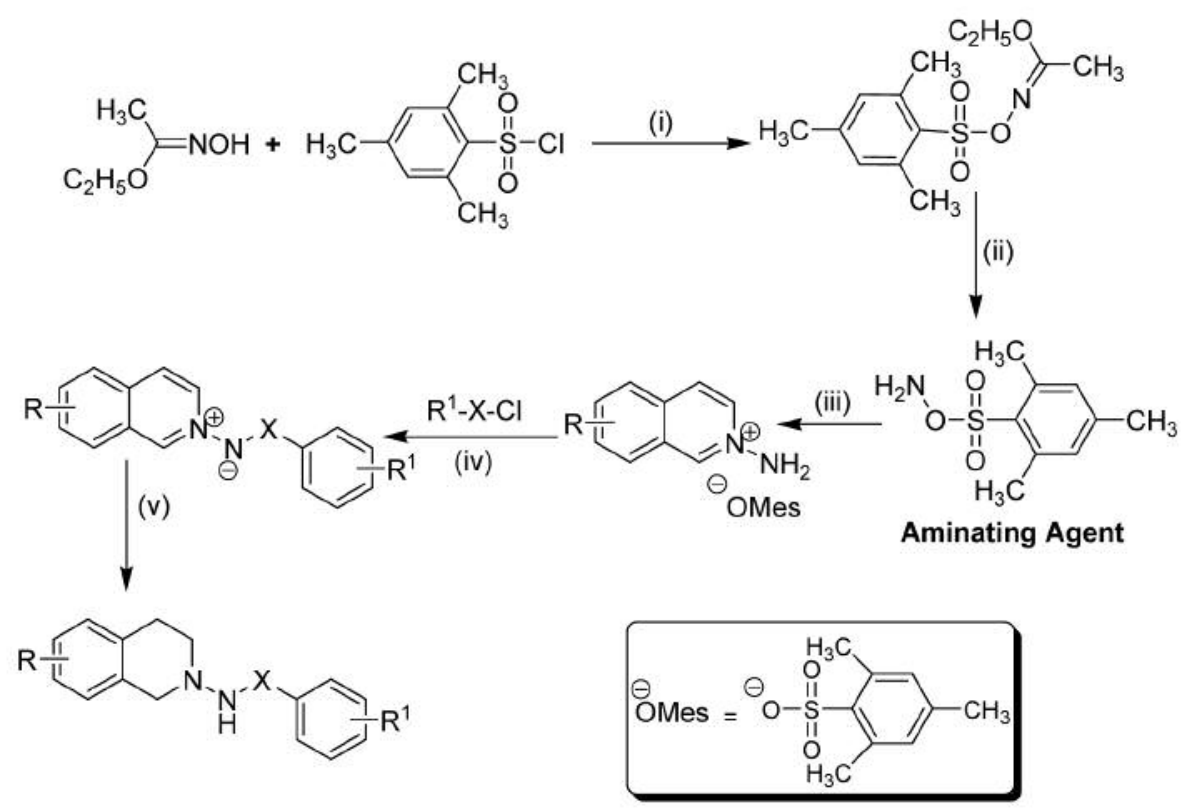

Reaction Conditions: (i) DMF, $0{ }^{\circ} \mathrm{C}, 45 \mathrm{~min}$, (ii) $70 \% \mathrm{HClO}_{4}, p$-dioxane, $0{ }^{\circ} \mathrm{C}, 45 \mathrm{~min}$, (iii) Substituted isoquinoline, dry $\mathrm{CH}_{2} \mathrm{Cl}_{2}$ : dry $\mathrm{MeOH}(2: 1), 0^{\circ} \mathrm{C}, 5 \mathrm{~h}$, (iv) 4-substituted acyl/sulfonyl chlorides, dry $\mathrm{THF}, 70^{\circ} \mathrm{C}$, $12 \mathrm{~h}$, (v) $\mathrm{NaBH}_{4}$, abs. EtOH, $7 \mathrm{~h} ; \mathrm{R}=\mathrm{OH}, \mathrm{Br} ; \mathrm{X}=\mathrm{CO}, \mathrm{SO}_{2} ; \mathrm{R}^{1}=4-\mathrm{C}_{2} \mathrm{H}_{5}$, 4-tert- $\mathrm{C}_{4} \mathrm{H}_{9}, 4-\mathrm{OCH}_{3}$, $2-\mathrm{OCH}_{3}, 2-\mathrm{C}_{2} \mathrm{H}_{5} ; \mathrm{X}=\mathrm{CO}, \mathrm{SO}_{2}$ 
cultured in ATCC-formulated Leibowitz's L-15 medium, supplemented with $10 \%$ fetal bovine serum (FBS) and penicillin/streptomycin $(100 \mathrm{U} / 0.1 \mathrm{mg} / \mathrm{ml})$. After confluence, the cells were sub-cultured and grown in Dulbecco's modified Eagle's medium (DMEM) containing phenol red, 10\% FBS, 4 mM L-glutamine, 20 $\mu \mathrm{M}$ sodium pyruvate and penicillin/streptomycin $(100 \mathrm{U} / 0.1 \mathrm{mg} / \mathrm{ml})$. Cells were maintained at $37^{\circ} \mathrm{C}$ in $5 \% \mathrm{CO}_{2} /$ atmosphere and every 25 days, the medium was replaced and cells sub-cultured. For experiments, plating medium consisted of DMEM with $1 \%$ (for determination of cell-cycle phase) or 5\% (for proliferation studies) FBS plus penicillin/streptomycin (100 U/0.1 mg/ml), $25 \mathrm{mM}$ glucose, $2 \mathrm{mM}$ sodium pyruvate and $3 \mathrm{mM}$ L-glutamine.

Proliferation studies. Compounds were dissolved in DMSO, vortexed and stored at $-20^{\circ} \mathrm{C}$ in the dark. A stock solution for all experimental compounds were prepared in HBSS plus $5 \mathrm{mM}$ HEPES, adjusted to a $\mathrm{pH}$ of 7. 4. Briefly, 96-well plates contained cells at a low cell plating density $\left(0.04 \times 10^{6} /\right.$ well $)$ to which compounds of equal concentration were added and cell proliferation was evaluated after $72 \mathrm{~h}$. Compounds were assessed for influence on cell count, ranked for potency, and 50\% inhibitory concentration $\left(\mathrm{IC}_{50}\right)$ values were calculated by regression analysis.

Viable cell count. Viable cells were quantified using resazurin (Alamar Blue) indicator dye. A working solution of resazurin was prepared in sterile phosphate-buffered saline (PBS)-phenol red $(0.5 \mathrm{mg} / \mathrm{ml})$ and added $(15 \% \mathrm{v} / \mathrm{v})$ to each sample in a 96 -well plate. Samples were returned to the incubator for 2-4 h, and reduction of the dye (to resorufin, a fluorescent compound) by viable cells was quantitatively analyzed using a Synergy HTX multi-mode reader (Bio-Tek, Winooski, VT, USA) with excitation/emission wavelength settings at 550/580.

$\left[{ }^{3} H\right]$ Thymidine incorporation $(T d R)$. Replicative DNA synthesis was assessed by radiolabeled incorporation of TdR. Briefly, cells were plated in 24-well plates, containing HBSS (control) or test compound then supplemented with $1.5 \mu \mathrm{Ci} / \mathrm{ml} \mathrm{TdR}$. After a $72-\mathrm{h}$ incubation period, the cells were scraped, centrifuged, pelleted and washed four times with PBS. A final rinse was achieved by cell redistribution in PBS and filtering through a $0.2 \mu \mathrm{m}$ microcentrifuge filter which was then placed in scintillation cocktail and vortexed for $30 \mathrm{sec} .\left[{ }^{3} \mathrm{H}\right]$ Radioactivity was determined using a Beckman LS 6500 liquid scintillation counter (Beckman- Coulter Inc, Indianapolis IN, USA).

Tubulin polymerization. Tubulin polymerization assay (Cytoskeleton, Inc., Denver, CO, USA) was used for determining the effects of drugs. The assay utilizes neuronal tubulin which creates a polymerization curve showing three stages of microtubule formation: nucleation, growth, and equilibrium, which were measured at over a 60-min period and maintained at a temperature of $40^{\circ} \mathrm{C}$. The data were acquired with a Synergy HTX multi-mode reader (Bio-Tek, Winooski, VT, USA) with excitation/emission wavelength settings at 340/460.

Cell imaging. Alexa Fluor ${ }^{\circledR} 488$ Phalloidin and propidium iodide (PI) fluorescent dyes were used to corroborate proliferation indirectly by DNA/cytoskeleton F-actin. Briefly, stock solutions containing fluorescent probes were prepared by dissolving $5 \mathrm{mg} / 1$ $\mathrm{ml}$ ethanol, which were then subsequently diluted in HBSS and

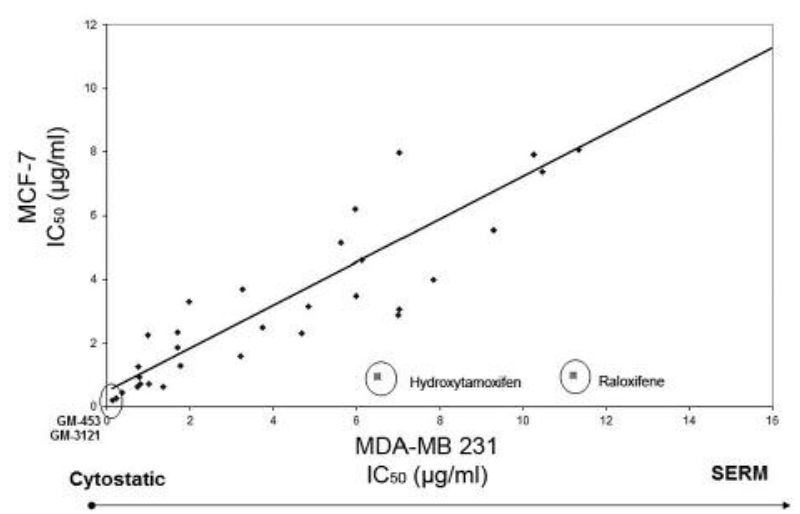

Figure 1. Correlation scatterplot to identify potential selective estrogen receptor modulators (SERM) drugs by evaluation of the antiproliferative effects in estrogen receptor-positive $\left(E R^{+}\right)$cells $(M C F$ 7) driven by estradiol vs. triple-negative (MDA-MB-231) cells. The data represent $50 \%$ inhibitory concentration $\left(I C_{50}\right)$ of each compound against each cell line.

added to cells: final dye concentration: $5 \mu \mathrm{g} / \mathrm{ml}$ PI and $6.6 \mu \mathrm{M}$ phalloidin. Photographic images for tubulin were acquired using a TubulinTracker ${ }^{\mathrm{TM}}$ Oregon Green ${ }^{\circledR} 488$ Taxol, bis-acetate probe. Samples were analyzed photographically using a fluorescent/ inverted microscope, CCD camera and data acquisition using ToupTek View (TouTek Photonics Co, Zhejiang, P.R China).

Determination of cell-cycle phase. Cells were plated in 24-well plates at $0.2 \times 10^{6}$ cells $/ \mathrm{ml}$ and cultured in low-serum medium for 24 $\mathrm{h}$ to synchronize the cell cycle. After 24 hours, the low-serum medium was removed, and DMEM with $5 \%$ FBS and $25 \mathrm{mM}$ glucose was added before treatment with test compounds cultured alongside both positive untreated controls and negative controls containing paclitaxel $(5 \mu \mathrm{M})$. After $24 \mathrm{~h}$, cells were trypsinized, centrifuged and washed twice with assay buffer (Cayman Chemical, Ann Arbor, MI, USA), re-suspended to a density of $10^{6} \mathrm{cell} / \mathrm{s} / \mathrm{ml}$ in a cell suspension, fixed and stored at $-20^{\circ} \mathrm{C}$. After $48 \mathrm{~h}$, fixative was removed, and the pellet was placed in $0.5 \mathrm{ml}$ of a staining solution containing PI and RNase. A solution The distribution of DNA in all cell-cycle phases was assayed by flow cytometry in replicates. The proportion of cells in each stage was assayed within $2 \mathrm{~h}$ by using an FACSCalibur flow cytometer (BD Biosciences, San Jose, CA, USA). In each sample, a total of 10,000 individual events from the gated subpopulation were analyzed separately. CellQuest software (BD Biosciences, San Jose, CA, USA) was used for acquisition and analysis of the data, and the percentage of cells in each phase was determined by using ModFit LT 3.0 software (Verity Software House, Topsham, ME, USA).

Data analysis. Statistical analysis was performed using Graph Pad Prism (version 3.0; Graph Pad Software Inc. San Diego, CA, USA) with the significance of the difference between groups assessed using a one-way ANOVA, followed by Tukey post hoc means comparison test or Student's $t$-test. $\mathrm{IC}_{50} \mathrm{~s}$ were determined by regression analysis using Origin Software (OriginLab, Northampton, MA, USA). 
Table I. Growth-inhibitory properties of derivatives on MDA-MB-231 human breast carcinoma cells. The data represent 72-h growth-inhibitory potency established by 50\% inhibitory concentration $\left(I C_{50}\right)$ calculated from regression analysis of a minimum of six concentrations between $169 n M-30 \mu M, n=4$. Lethal concentrations $50\left(L C_{50}\right.$ s) were all in excess of $30 \mu M$, reflecting lack of toxicity at $24 \mathrm{~h}$.

\begin{tabular}{|c|c|c|c|c|}
\hline ID & Compound & Structure & $\mathrm{IC}_{50}(\mu \mathrm{M})$ & $\mathrm{LC}_{50}(\mu \mathrm{M})$ \\
\hline & Paclitaxel & & $<0.169$ & $>30$ \\
\hline 1 & GM-4-53 & & 1.12 & $>30$ \\
\hline 2 & GM-3-121 & & 2.11 & $>30$ \\
\hline 3 & GM-3-135 & & 3.56 & $>30$ \\
\hline 4 & GM-3-18 & & 5.58 & $>30$ \\
\hline 5 & GM-3-122 & & 6.29 & $>30$ \\
\hline 6 & GM-3-13 & & 6.78 & $>30$ \\
\hline 7 & GM-3-16 & & 9.30 & $>30$ \\
\hline 8 & GM-3-19 & & $>30$ & $>30$ \\
\hline 9 & GM3-15 & & $>30$ & $>30$ \\
\hline 10 & GM-3-143 & & $>30$ & $>30$ \\
\hline
\end{tabular}


Table I. Continued

\begin{tabular}{|c|c|c|c|c|}
\hline ID & Compound & Structure & $\mathrm{IC}_{50}(\mu \mathrm{M})$ & $\mathrm{LC}_{50}(\mu \mathrm{M})$ \\
\hline 11 & GM-4-5 & & $>30$ & $>30$ \\
\hline 12 & GM-3-180 & & $>30$ & $>30$ \\
\hline 13 & GM-3-146 & & $>30$ & $>30$ \\
\hline 14 & GM-3-178 & & $>30$ & $>30$ \\
\hline 15 & GM-3-162 & & $>30$ & $>30$ \\
\hline 16 & GM-3-174 & & $>30$ & $>30$ \\
\hline 17 & GM-3177 & & $>30$ & $>30$ \\
\hline 18 & GM-3-155 & & $>30$ & $>30$ \\
\hline 19 & GM-3-168 & & $>30$ & $>30$ \\
\hline 20 & GM-3-123 & & $>30$ & $>30$ \\
\hline
\end{tabular}


Table I. Continued

\begin{tabular}{|c|c|c|c|c|}
\hline ID & Compound & Structure & $\mathrm{IC}_{50}(\mu \mathrm{M})$ & $\mathrm{LC}_{50}(\mu \mathrm{M})$ \\
\hline 21 & GM-3-144 & ${ }_{\mathrm{OCH}_{3}}^{\mathrm{OCH}_{3}}$ & $>30$ & $>30$ \\
\hline 22 & GM-3-148 & $\mathrm{C}\left(\mathrm{CH}_{3}\right)_{3}$ & $>30$ & $>30$ \\
\hline 23 & GM-3-150 & $\mathrm{O}$ & $>30$ & $>30$ \\
\hline 24 & GM-3-172 & & $>30$ & $>30$ \\
\hline 25 & GM-3-156 & & $>30$ & $>30$ \\
\hline
\end{tabular}

\section{Results}

Antiproliferative effects of synthesized THIQs were initially evaluated by generating a scatterplot with $\mathrm{IC}_{50}$ values for each THIQ against MCF-7 (ER ${ }^{+}$) cells treated with estradiol versus those against MDA-MB-231 TNBC cells. A differential becomes evident where selective estrogen receptor modulators (SERM) positive controls (Raloxifene, hydroxytamoxifen) have specificity for halting proliferation in estradiol-treated MCF-7 cells, being relatively weak against TNBC cells (Figure 1). Figure 1 demonstrates a lack of SERM characteristics of any THIQ synthesized, which inhibited growth equally in receptor positive or negative cell lines. All compounds were evaluated for antiproliferative effects, with the $\mathrm{IC}_{50}$ given in Table I and regression analysis for the most potent THIQs GM-4-53 and GM-3-121 in Figure 2. GM-4-53 and GM-3-121 were equally effective in halting proliferation without toxicity.

GM-4-53 and GM-3-121 were further evaluated for effects on replicative DNA synthesis using radio-labeled incorporation of TdR (Figure 3), findings which showed significant losses that would otherwise be required for cell division. Likewise, these changes correlated with static cytoskeletal changes fostering giant multinucleated cells in a similar fashion often reported for paclitaxel $(20,21)$ (Figure 4A). These changes occurred tantamount to altered polymerized tubulin (Figure 4B) which is otherwise required to disassemble and reform into spindle platforms for chromosome assembly during cell division. While it is known that paclitaxel basically prevents the de-polymerization of microtubules, how GM-4-53 and GM-3-121 alter polymerization is unknown.

In the next part of the study, we assessed ex vitro tubulin polymerization, (Figure 5). The data showed that both THIQs prevented the formation of polymerized tubulin, in contrast to paclitaxel which blocked the de-polymerization process. While these findings corroborate that GM-4-53 and GM-3-121 indeed work as microtubule de-stabilizing agents, effects on the phase of cell cycle halted in mitosis are unknown. We next evaluated interference with the cell cycle compared to paclitaxel using flow cytometry (Figure 6A-B), results which showed comparable mitotic arrest at the $\mathrm{G}_{2}$ growth phase. 

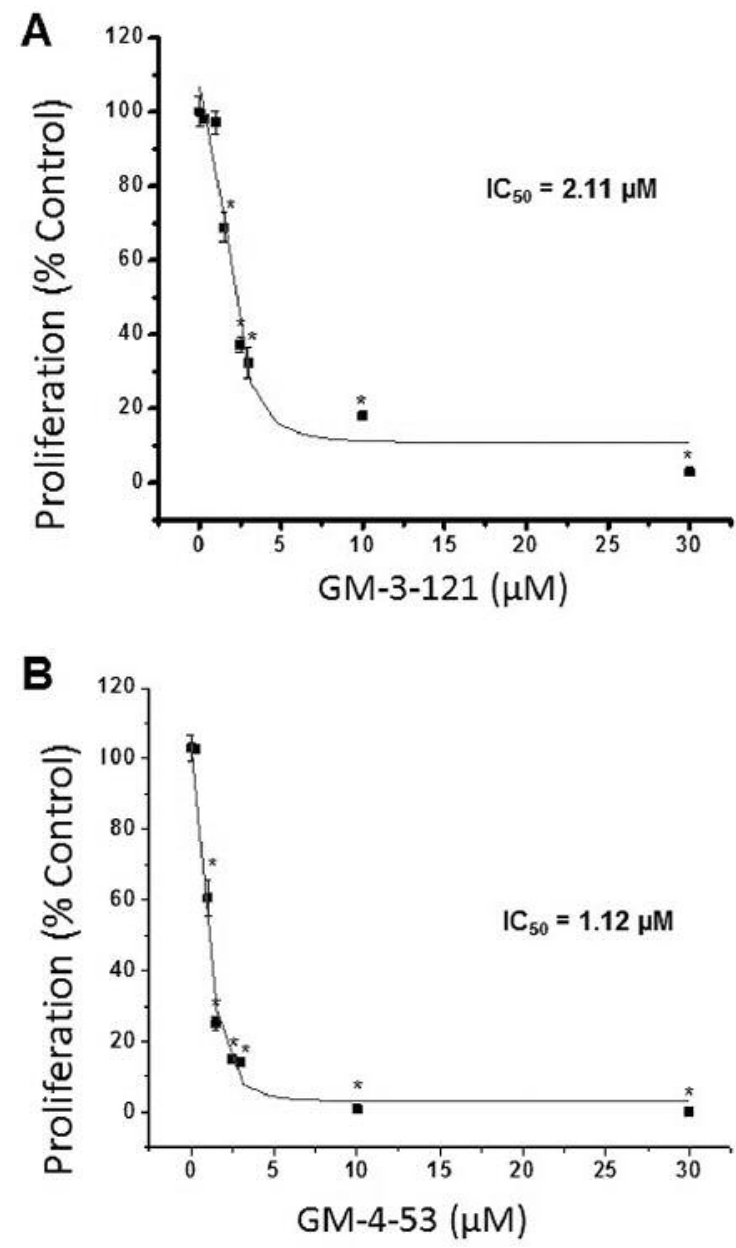

Figure 2. Growth-inhibitory dose-response profiles for lead antiproliferative drugs: GM-4-53 and GM-3-121. The data represent proliferation relative to the control and are presented as the mean \pm S.E.M., $n=4 .{ }^{*} p<0.05$ : Significantly differentt from the control with a one-way ANOVA followed by a Tukey post hoc test.

\section{Discussion}

TNBC is typically defined by the absence of hormone receptor expression (ER, PR and HER2). Lack of hormone receptor expression equals to limited treatment options, due to the lack of any effect of hormonal receptor antagonists (fulvestrant, tamoxifen) or aromatase inhibitors (exemestane, letrozole), and a greater reliance on cytostatic taxane drugs. While taxanes are considered first-line drugs for TNBC, alternative and augmentative adjunct therapies are being explored, including applications using THIQ derivatives. While there is meager research in this particular area, there is an indication that a combination of THIQs with taxanes could overcome multidrug resistance $(8,9)$ and at the same time augment cytostatic effects of microtubule-binding agents (12-14).

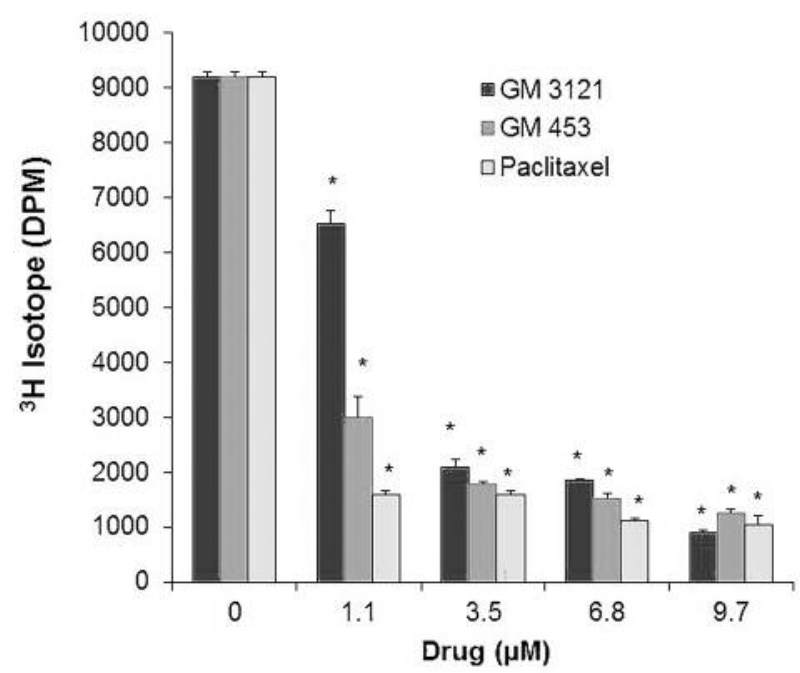

Figure 3. Effect of paclitaxel, GM-4-53 and GM-3-121 on replicative DNA synthesis. The data represent radiolabeled incorporation of $\left[{ }^{3} \mathrm{H}\right]$ thymidine (TdR) after $72 \mathrm{~h}$, under various treatments. The data represent disintegrations per minute $(D P M)$ as a percentage of the control and are presented as the mean \pm S.E.M., $n=4$. *Significantly different from the untreated controls at $p<0.05$ using a one-way ANOVA followed by a Tukey post hoc test.

In this study, we synthesized, evaluated and confirmed the efficacy of different THIQ compounds in blocking mitosis, altering cytoskeletal features and arresting cell progression at the $\mathrm{G}_{2}$ phase relative to paclitaxel in TNBC. These findings show THIQs to be relatively weak in strength compared to paclitaxel, where neither of these mediate effects via antagonizing the ER, evidenced by equal efficacy in estradiol-driven growth in MCF7 cells $v s$. TNBC MDAMB-231 cells. On the other hand, while paclitaxel and THIQs both negatively affect polymerization of tubulin, resulting in halt of cell proliferation, the manner in which THIQs target tubulin differs from that of paclitaxel. These findings suggest that THIQs block the polymerization of tubulin, whereas paclitaxel prevents de-polymerization, both of which result in net loss of microtubule assembly. A negative impact on tubulin by either process would then prevent chromosomes from achieving a metaphase spindle configuration, which would then lead to halted mitosis, as found here. Using immunocytochemistry, we demonstrate that both THIQs and paclitaxel are associated with formation of giant multinucleated cells, with grossly abnormal actin and tubulin orientation, a known consequence of mitotic catastrophe and disturbed cytokinesis (21-23).

The correlation of structure and activity indicate the importance of the basic structural characteristics of these cytostatic compounds (Table I), where the substituents at the para position, especially the lower alkyl chains such ethyl and 
A

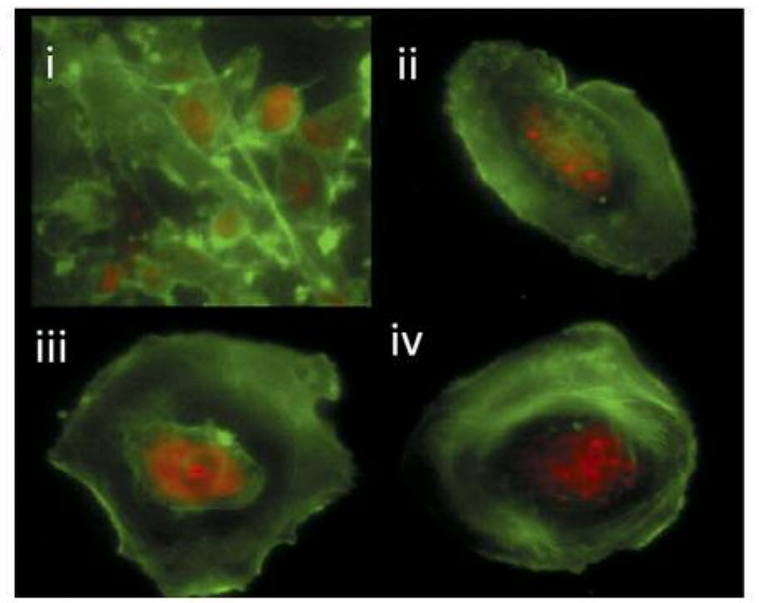

B

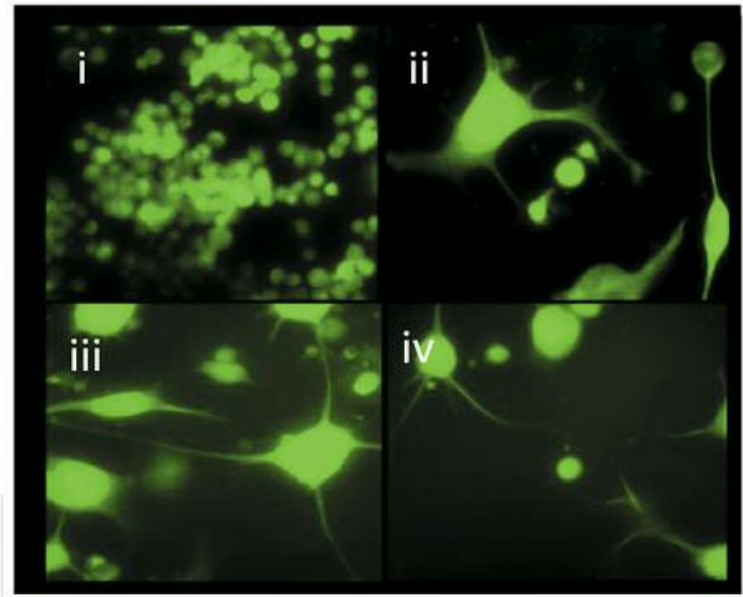

Figure 4. Antiproliferative effects of agents compared with the control in MDA-MB-231 cells. A: Actin cytoskeletal changes shown by fluorescence-stained actin: Alexa Fluor ${ }^{\circledR} 488$ Phalloidin, with a nuclear counterstain of propidium iodide. B: Polymerized tubulin structure in MDA-MB-231 cells as shown by fluorescence-stained tubulin: Tubulin Tracker $^{T M}$ Green (Oregon Green ${ }^{\circledR} 488$ Taxol, bis-acetate). i: Control; ii: paclitaxel (5 $\mu M)$; iii: GM-4-53 (5 $\mu M)$; and iv: GM-3-121(5 $\mu M)$.

propyl moieties, and ortho, para directing substituents such as $\mathrm{Br}, \mathrm{Cl}$ and $\mathrm{OCH}_{3}$ on the $\mathrm{N}$-substituted phenyl ring contributed to the antiproliferative activity. On the other hand, various $\mathrm{N}$ substituted heterocycles, meta directing and electronegative substituents, methyl and higher alkyl chains and alkoxides even on the para position of the benzene ring or heterocycle did not contribute to the biological activity. Apart from the para position, substitutions at all other positions resulted in a decrease in activity. These initial results would guide us in the product optimization studies in the future.

Further work will be required to derivatize the lead structures in order to gain greater potency, to assess molecular targets in detail, and determine if these compounds can affect the tubulin colchicine site, which

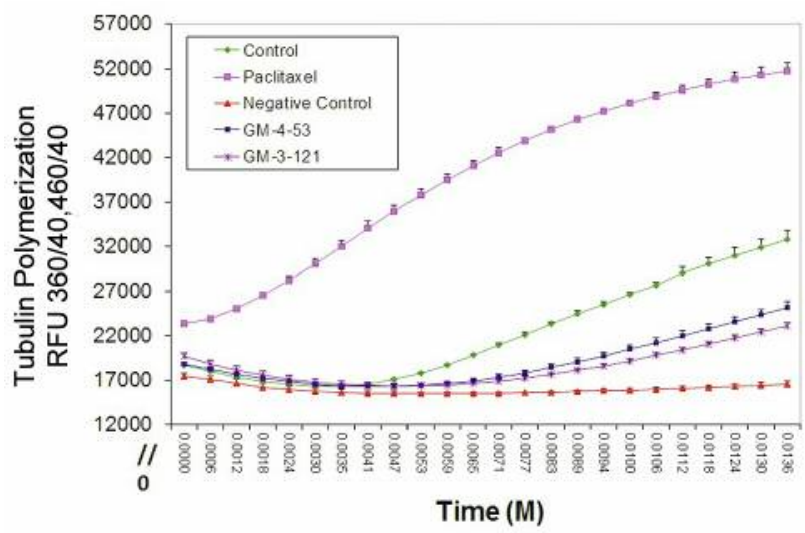

Figure 5. Porcine tubulin fluorescence-based polymerization and subsequent formation of microtubules. The data represent time-dependent tubulin polymerization assessed by fluorescence reporter (RFU) in the presence of distilled water (control), $10 \mu \mathrm{M}$ of paclitaxel (positive control), $100 \mu \mathrm{M} \mathrm{CaCl}_{2}$ (negative control), and $100 \mu \mathrm{M}$ of GM-4-53 and GM-3-121. The data are presented as the mean \pm S.E.M, $n=3$.

could provide a means of overcoming multidrug resistance, in particular to taxanes (24).

\section{Acknowledgements}

This research was supported by the National Institute of Minority Health and Health Disparities of the National Institutes of Health through Grant Number 8 G12MD007582-28 and Grant Number 1P20 MD006738-01.

\section{References}

1 Chen JQ and Russo J: ERalpha-negative and triple-negative breast cancer: Molecular features and potential therapeutic approaches. Biochim Biophys Acta 1796(2): 162-175, 2009.

2 Sasaki Y and Tsuda H: Clinicopathological characteristics of triple-negative breast cancers. Breast Cancer 16(4): 254-259, 2009.

3 Gluz O, Liedtke C, Gottschalk N, Pusztai L, Nitz U and Harbeck $\mathrm{N}$ : Triple-negative breast cancer-current status and future directions. Ann Oncol 20(12): 1913-1927, 2009.

4 Pal SK and Mortimer J: Triple-negative breast cancer: Novel therapies and new directions. Maturitas 63(4): 269-274, 2009.

5 de Ruijter TC, Veeck J, de Hoon JP, van Engeland M and TjanHeijnen VC: Characteristics of triple-negative breast cancer. J Cancer Res Clin Oncol 137(2): 183-192, 2011.

6 Verma S, Provencher L and Dent R: Emerging trends in the treatment of triple-negative breast cancer in canada: A survey. Curr Oncol 18(4): 180-190, 2011.

7 Akasbi Y, Bennis S, Abbass F, Znati K, Joutei KA, Amarti A and Mesbahi OE: Clinicopathological, therapeutic and prognostic features of the triple-negative tumors in moroccan breast cancer patients (experience of Hassan II University Hospital in Fez). BMC Res Notes 4: 500, 2011. 

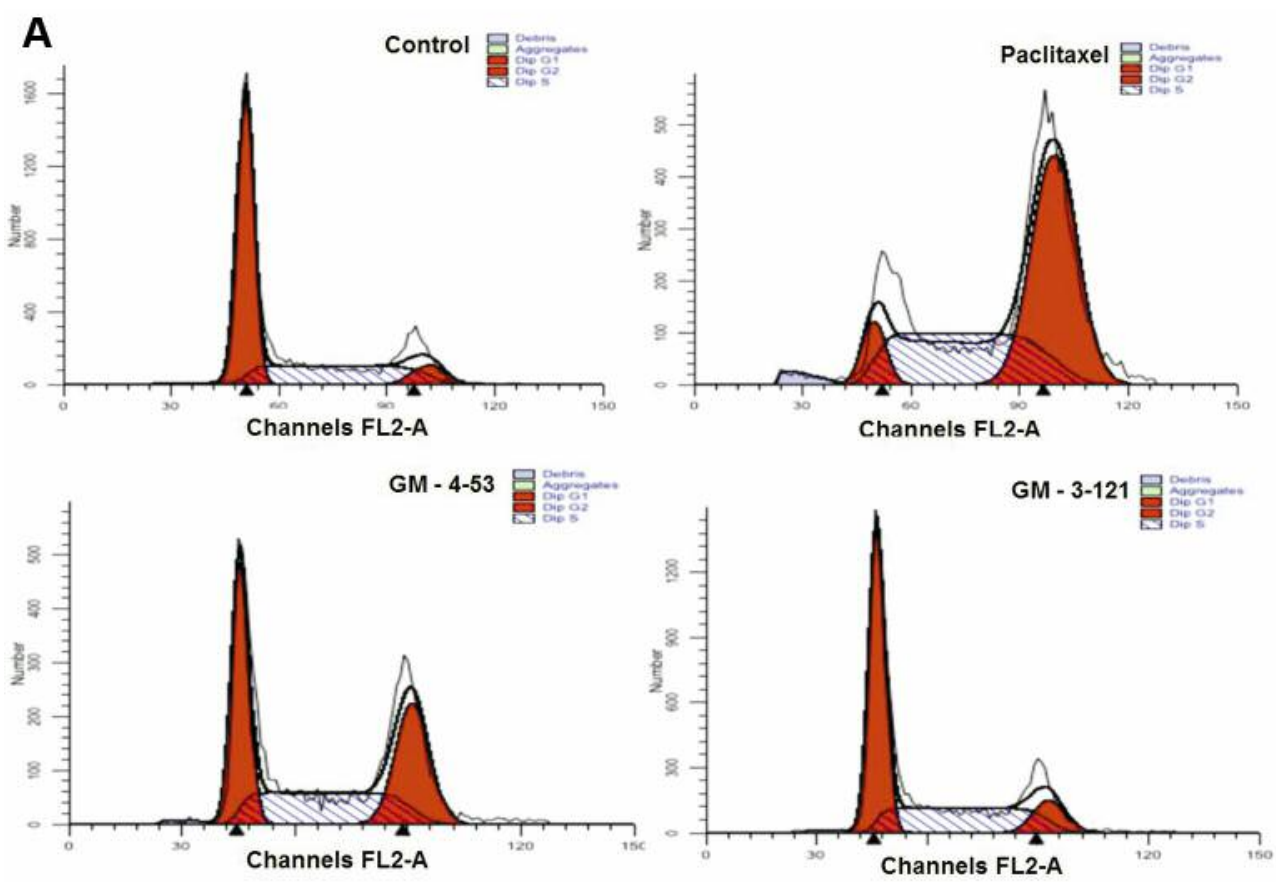

B
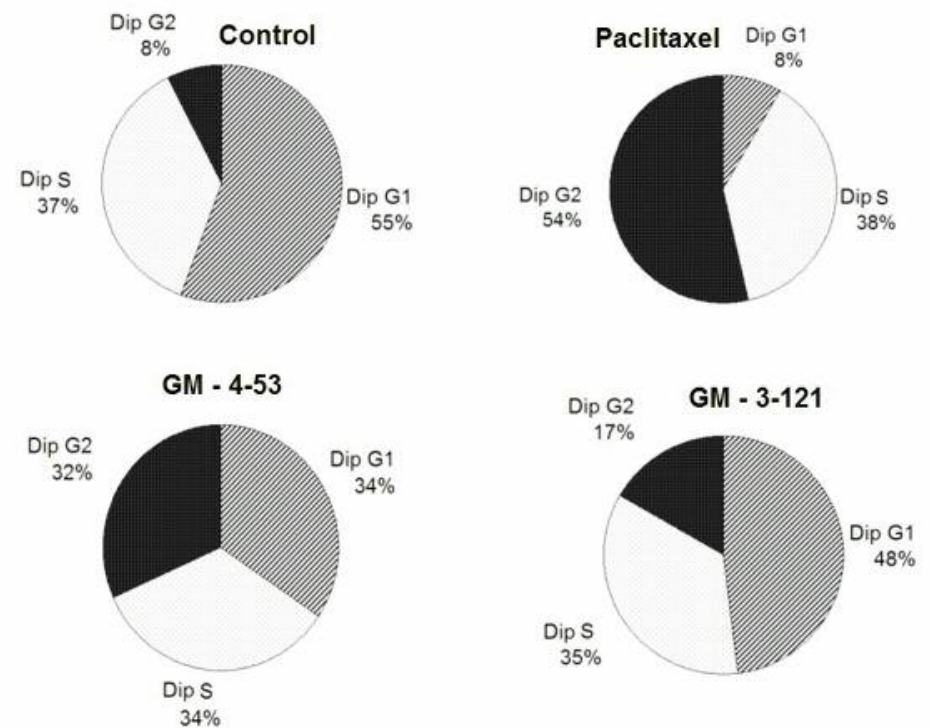

Figure 6. The effect of paclitaxel, GM-3-121, and GM-4-53 all evaluated at $5 \mu M v s$. the control on the gated population and cell-cycle distribution in MDA-MB 231 cells after cell synchronization and a subsequent 24-h exposure period. The data are expressed as the percentage phase count presented as a histogram $(A)$ and pie chart $(B)$ determined from experimental replicates. Dip, Diploid.

8 Mihalyi A, Gaspar R, Zalan Z, Lazar L, Fulop F and de Witte PA: Synthesis and multidrug resistance reversal activity of $1,2-$ disubstituted tetrahydroisoquinoline derivatives. Anticancer Res 24(3a): 1631-1636, 2004.

9 Liu B, Qiu Q, Zhao T, Jiao L, Li Y, Huang W and Qian H: 6,7dimethoxy-2-\{2-[4-(1h-1,2,3-triazol-1-yl)phenyl]ethyl\}-1,2,3,4- tetrahydroisoquinolines as superior reversal agents for Pglycoprotein-mediated multidrug resistance. ChemMedChem 10(2): 336-344, 2015.

10 Kohler SC and Wiese M: HM30181 derivatives as novel potent and selective inhibitors of the breast cancer resistance protein (BCRP/ABCG2). J Med Chem 58(9): 3910-3921, 2015. 
11 Song S, Li X, Guo J, Hao C, Feng Y, Guo B, Liu T, Zhang Q, Zhang Z, Li R, Wang J, Lin B, Li F, Zhao D and Cheng M: Design, synthesis and biological evaluation of 1-phenanthryltetrahydroisoquinoline derivatives as novel p21-activated kinase 4 (PAK4) inhibitors. Org Biomol Chem 13(12): 3803-3818, 2015.

12 Atmaca $\mathrm{H}$ and Uzunoglu S: Anti-angiogenic effects of trabectedin (yondelis; ET-743) on human breast cancer cells. Eur Cytokine Netw 25(1): 1-7, 2014.

13 Kumar P, Rawat A, Keshari AK, Singh AK, Maity S, De A, Samanta A and Saha S: Antiproliferative effect of isolated isoquinoline alkaloid from Mucuna pruriens seeds in hepatic carcinoma cells. Nat Prod Res 30(4): 460-463, 2016.

14 Lane JW, Estevez A, Mortara K, Callan O, Spencer JR and Williams RM: Antitumor activity of tetrahydroisoquinoline analogues 3-epi-jorumycin and 3-epi-renieramycin G. Bioorg Med Chem Lett 16(12): 3180-3183, 2006.

15 Acikgoz E, Guven U, Duzagac F, Uslu R, Kara M, Soner BC and Oktem $\mathrm{G}$ : Enhanced $\mathrm{G}_{2} / \mathrm{M}$ arrest, caspase related apoptosis and reduced E-cadherin dependent intercellular adhesion by trabectedin in prostate cancer stem cells. PLoS One 10(10): e0141090, 2015.

16 Gangapuram M, Mazzio E, Eyunni S, Soliman KF and Redda KK: Synthesis and biological evaluation of substituted $n$-[3-(1hpyrrol-1-yl)methyl]-1,2,5,6-tetrahydropyridin-1-yl] benzamide/ benzene sulfonamides as anti-inflammatory agents. Arch Pharm 347(5): 360-369, 2014.

17 Gangapuram M, Eyunni S and Redda KK: Synthesis and pharmacological evolution of tetrahydroisoquinolines as anti breast cancer agents. J Cancer Sci Ther 6: 161-169, 2014.

18 Eyunni SK, Gangapuram $\mathrm{M}$ and Redda KK: In vitro antiproliferative activity of new tetrahydroisoquinolines (THIQs) on ishikawa cells and their 3D pharmacophore models. Lett Drug Des Discov 11(4): 428-436, 2014.

19 Tamura Y, Minamikawa J, Miki Y, Matsugashita S and Ikeda M: A novel method for heteroaromatic $N$-imines. Tetrahedron Lett 40: 4133-4135, 1972.
20 Perchellet JP, Perchellet EM, Singh CR, Monnett MT, Studer ER, Thornton PD, Brown N, Hill D, Neuenswander B, Lushington GH, Santini C and Buszek KR: Mechanisms by which synthetic 6,7-annulated-4-substituted indole compounds with anti-proliferative activity disrupt mitosis and block cytokinesis in human HL-60 tumor cells in vitro. Anticancer Res 34(4): 1643-1655, 2014.

21 Zhu J, Beattie EC, Yang Y, Wang HJ, Seo JY and Yang LX: Centrosome impairments and consequent cytokinesis defects are possible mechanisms of taxane drugs. Anticancer Res 25(3B): 1919-1925, 2005.

22 Wang H, Zuo B, Wang H, Ren L, Yang P, Zeng M, Duan D, Liu $\mathrm{C}$ and $\mathrm{Li} \mathrm{M}$ : Cgk733 enhances multinucleated cell formation and cytotoxicity induced by taxol in CHK1-deficient HBV-positive hepatocellular carcinoma cells. Biochem Biophys Res Commun 422(1): 103-108, 2012.

23 Trendowski M, Wong V, Yu G and Fondy TP: Enlargement and multinucleation of U937 leukemia and MCF7 breast carcinoma cells by antineoplastic agents to enhance sensitivity to low frequency ultrasound and to DNA-directed anticancer agents. Anticancer Res 35(1): 65-76, 2015.

24 Salum LB, Mascarello A, Canevarolo RR, Altei WF, Laranjeira AB, Neuenfeldt PD, Stumpf TR, Chiaradia-Delatorre LD, Vollmer LL, Daghestani HN, de Souza Melo CP, Silveira AB, Leal PC, Frederico MJ, do Nascimento LF, Santos AR, Andricopulo AD, Day BW, Yunes RA, Vogt A, Yunes JA and Nunes RJ: $N$-(1'-Naphthyl)-3,4,5-trimethoxybenzohydrazide as microtubule destabilizer: Synthesis, cytotoxicity, inhibition of cell migration and in vivo activity against acute lymphoblastic leukemia. Eur J Med Chem 96: 504-518, 2015.

Received August 18, 2016

Revised September 6, 2016

Accepted September 12, 2016 